\title{
Isolated Bidirectional DC-DC Converter for SuperCapacitor Applications
}

Dehnavi, Sayed M. D.; Sen, Gökhan; Thomsen, Ole Cornelius; Andersen, Michael A. E.; Møller, Lars

Published in:

ICREPQ'11 International Conference on Renewable Energies and Power Quality

Publication date:

2011

Link back to DTU Orbit

Citation (APA):

Dehnavi, S. M. D., Sen, G., Thomsen, O. C., Andersen, M. A. E., \& Møller, L. (2011). Isolated Bidirectional DC-DC Converter for SuperCapacitor Applications. In ICREPQ'11 International Conference on Renewable Energies and Power Quality

\section{General rights}

Copyright and moral rights for the publications made accessible in the public portal are retained by the authors and/or other copyright owners and it is a condition of accessing publications that users recognise and abide by the legal requirements associated with these rights.

- Users may download and print one copy of any publication from the public portal for the purpose of private study or research.

- You may not further distribute the material or use it for any profit-making activity or commercial gain

- You may freely distribute the URL identifying the publication in the public portal

If you believe that this document breaches copyright please contact us providing details, and we will remove access to the work immediately and investigate your claim. 
European Association for the Development of Renewable Energies, Environment and Power Quality (EA4EPQ)
International Conference on Renewable Energies and Power Quality (ICREPQ'11)

Las Palmas de Gran Canaria (Spain), 13th to 15th April, 2010

\title{
Isolated Bidirectional DC-DC Converter for SuperCapacitor Applications
}

\author{
Sayed M. D. Dehnavi ${ }^{1}$, Gokhan Sen ${ }^{2}$, Ole C. Thomsen², Michael A. E. Andersen², and Lars Møller ${ }^{3}$ \\ ${ }^{1}$ Power Electronic \& Protection Lab. \\ Faculty of Electrical and Computer Engineering, \\ Tarbiat Modares University, Jalal Ale Ahmad HWY, Tehran, Iran \\ ${ }^{2}$ Department of Electrical Engineering, \\ Technical University of Denmark, Kgs. Lyngby, DK-2800, Denmark, \\ gs@elektro.dtu.dk \\ ${ }^{3}$ H2 Logic A/S \\ Herning, DK-7400, Denmark
}

\begin{abstract}
This paper proposes a new bidirectional DC/DC converter for supercapacitor applications. The proposed converter has a parallel structure in supercapacitor side (where voltage is low and current is high) and a series structure in the other side. This structure increases efficiency of the converter. For current sharing in the parallel side of the proposed converter, two different methods are recommended and compared in this paper: Current balancing transformer (CBT) and two separate inductors (TSI). Simulation and experimental results show performance of the proposed converter.
\end{abstract}

\section{Key words}

Current sharing, parallel primary, bidirectional converter, supercapacitor, fuel cell.

\section{Introduction}

Currently fuel cell electric vehicles (FCEV) are considered as an attractive option for future cars because of environmental issues and alternative energy requirements. However since fuel cell stack has a slow response, using an auxiliary energy storage device such as battery or supercapacitor (SC) is recommended in the fuel cell (FC) applications [1-3]. While the battery has a large energy density and SC has a high power density, FC-Battery hybrid and FC-SC hybrid systems offer different features. However, FC-SC-Battery hybrid systems in Fig. 1 have been shown to have superior features [2-3].

Because of charge dependent voltage of SC, a bidirectional DC/DC converter is needed for bidirectional power exchange between SC and other parts of the system for different voltage levels [2-4]. Isolated full-bridge converter in Fig. 2 is a common DC/DC converter topology [5-6]. For high power applications, parallel isolated full-bridge converters have been proposed [7]. In fuel cell applications, generally low voltage is required to be boosted to higher voltages. Fig. 3 shows the primary parallel isolated boost converter proposed in [8] which is suitable for high voltage gain applications. This converter is composed of full-bridge stages with parallel primary connections (where current is high and voltage is low) and a single rectification stage with series secondary connection (where current is low and voltage is high). Current sharing is ensured by the series connection of transformer secondary windings and small cascaded current balancing transformer (CBT) on the primary side.

In this paper, the unidirectional converter presented in [8] is modified to handle bidirectional power flow in energy storage applications. For this purpose, the diode bridge rectifier on the secondary side has been replaced with a full bride inverter. In addition a detailed analysis has been carried out comparing two different current balancing configurations. Using two separate inductors (TSI) instead of current balancing transformer (CBT) is recommended due to cost and simplicity. It has been shown that the current sharing performance is similar in both cases. 


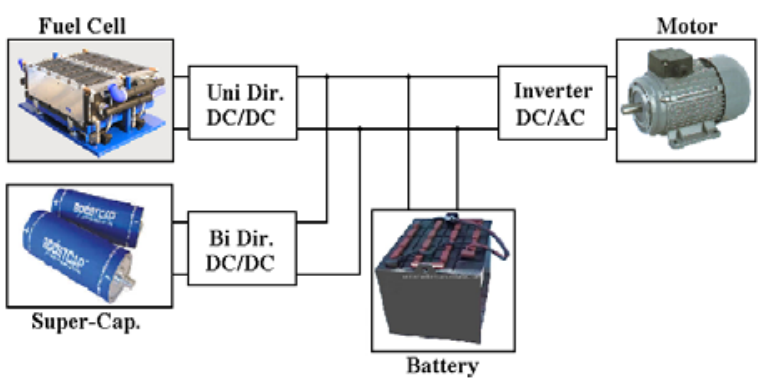

Fig. 1. FC-SC-Battery hybrid system.

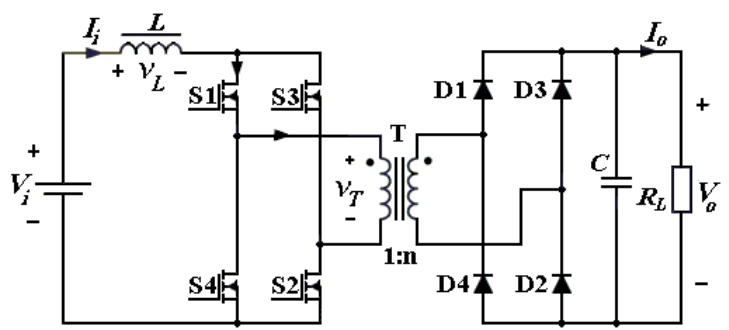

Fig. 2. Isolated full-bridge DC/DC converter.

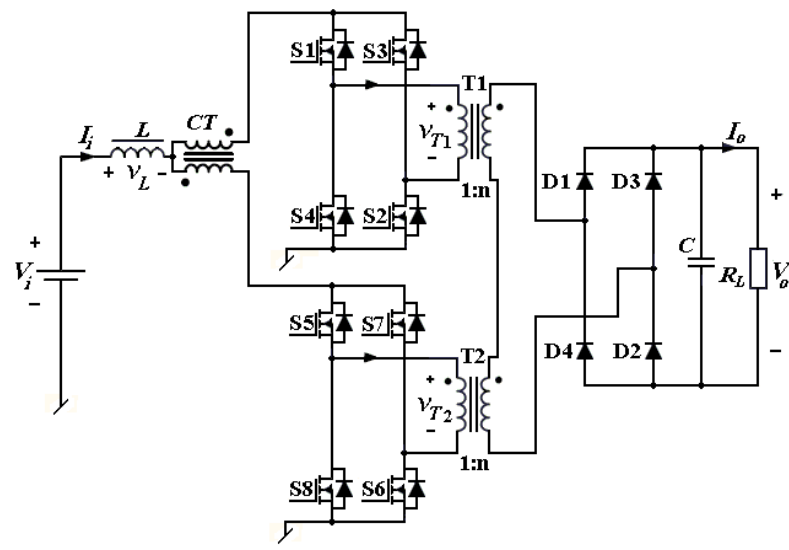

Fig. 3. High-efficiency isolated DC/DC converter.

\section{Bi-directional DC/DC Converter}

Fig. 4 shows the modified bidirectional DC/DC converter suitable for SC applications. The converter includes two full-bridge stages in the primary side and one in the secondary. Two inductors with the same value $\left(L_{1}=L_{2}\right)$ are used as boosting elements. This configuration (TSI) can eliminate the requirement of current balancing transformer (CBT). The proposed converter has two discharging and charging operating states. These states will be illustrated in the following sections.

Fig. 5 shows the gate signals for the proposed converter. The gate signals for the primary side switches are similar to the original unidirectional configuration. The gate signals for the secondary side can be produced using the logical NOT of the gate signals of primary side switches. However to avoid short-circuit in the output, dead-time should be considered.

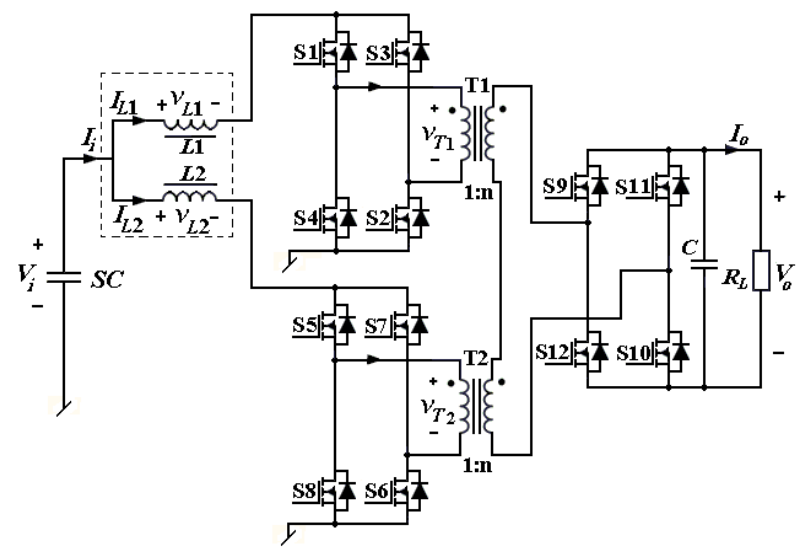

Fig. 4. Proposed isolated bi-directional DC/DC converter.

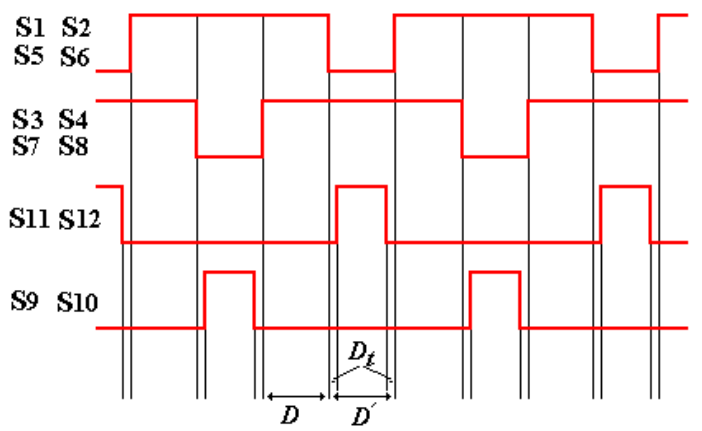

Fig. 5. Gate signals of proposed converters.

\section{Normal Operation Modes}

The proposed converter can be simply modeled as in Fig. 6a and Fig. 6b for CBT and TSI configurations, respectively. Upper and lower primary full-bridge stages have been modeled by switches $S_{m 1}$ and $S_{m 2}$ and secondary side bridge has been modeled by $S_{m}$.

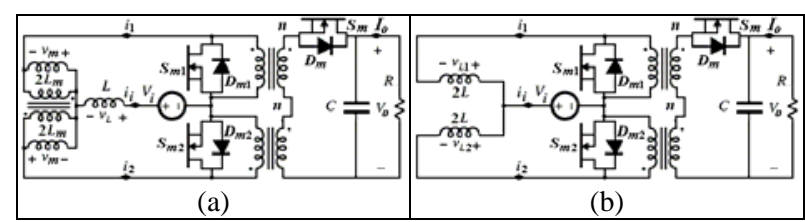

Fig. 6. Simplified models of the proposed conveteter: a) CBT b) TSI.

\section{A. Discharge state}

In the discharging of SC, secondary inverter acts as a rectifier. Considering the gate signals in Fig. 5, two main operation modes can be defined for the converter.

1) Mode 1: Both $S_{M 1}$ and $S_{M 2}$ are closed and inductors are charging (Fig. 7).

2) Mode 2: Both $S_{M 1}$ and $S_{M 2}$ are open and inductors are discharging (Fig. 8). 
Fig. 9 shows waveforms for both inductor configurations. For the same ripple current, inductance of each inductors of TSI topology is twice of inductance of inductor of CBT topology. It can be proven for both cases that:

$V_{o}=\frac{2 n}{D^{\prime}} V_{i}$

$$
I_{i}=\frac{2 n}{D^{\prime}} I_{o}
$$

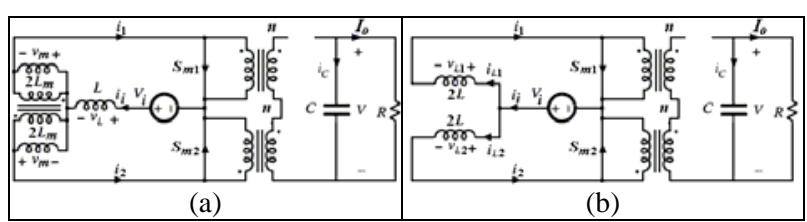

Fig. 7. Model of proposed conveteters in mode 1 of of discharging state: a) CBT b) TSI.

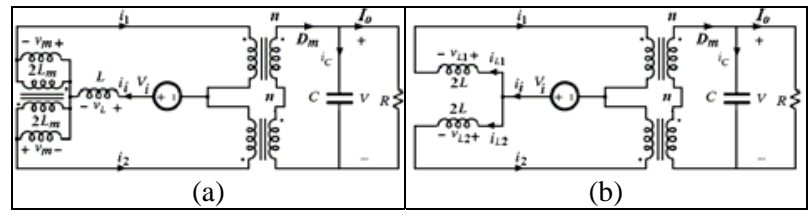

Fig. 8. Model of proposed conveteters in mode 2 of of discharging state: a) CBT b) TSI.

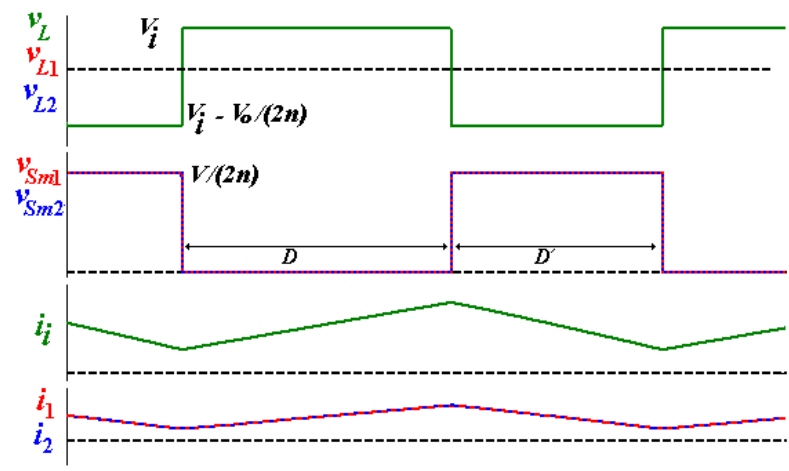

Fig. 9. Waveforms of proposed converters in normal modes of discharging state.

\section{B. Charge state}

Primary side full-bridge stages act as rectifiers during the charging of the SC. Similar to the discharge state, two main operation modes can be considered in the charge state.

1) Mode 1: Both diodes $D_{M 1}$ and $D_{M 2}$ are conducting and inductors (or inductor) are discharging (Fig. 10).

2) Mode 2: Both $D_{M 1}$ and $D_{M 2}$ are open and inductors (or inductor) are charging (Fig. 11).

Fig. 12 shows waveforms for both configurations. Neglecting deadtime, it can be proved that (1) and (2) are correct in the charge state. However considering deadtime (Fig. 5), it can be written:

$$
\begin{aligned}
& V_{o}=\frac{2 n}{D^{\prime}-2 D_{t}} V_{i} \\
& I_{i}=\frac{2 n}{D^{\prime}-2 D_{t}} I_{o}
\end{aligned}
$$

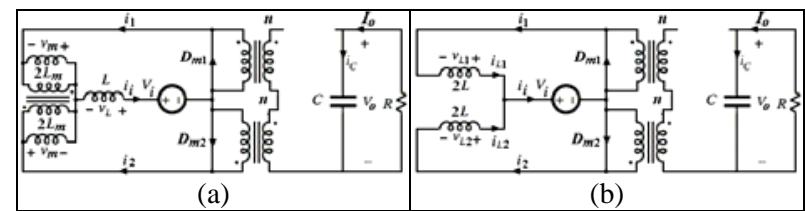

Fig. 10. Model of proposed conveteters in mode 1 of of charging state: a) CBT b) TSI.

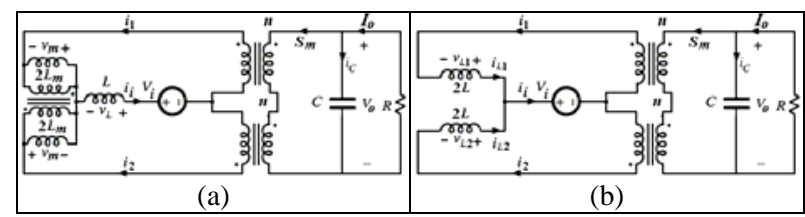

Fig. 11. Model of proposed conveteters in mode 2 of of charging state: a) CBT b) TSI.

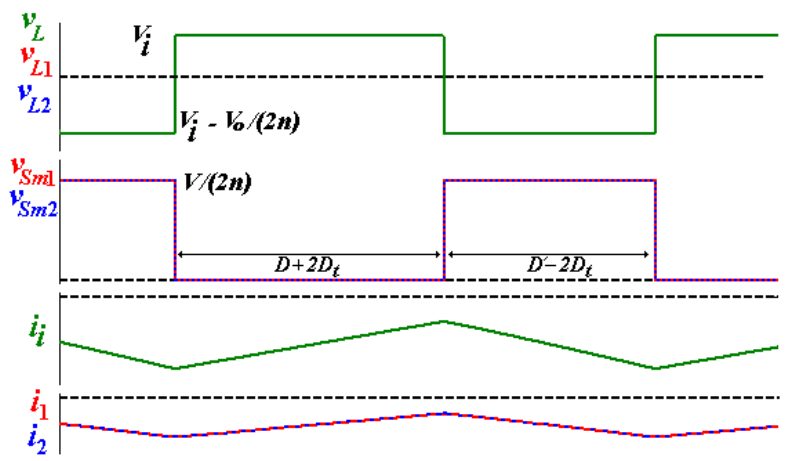

Fig. 12. Waveforms of proposed converters in normal modes of charging state.

\section{Extra Operation Modes}

In the previous section, it is assumed that both primary side switches are switched at same time. However it is possible that this assumption is not satisfied because of differences in component propagation delays and parasitic elements. Considering a single boosting inductor (without CBT), when one of the simplified switches in Fig. 6 is ON, all the current $i_{i}$ passes through the corresponding bridge. However in CBT and TSI configurations, due to the high impedance seen between the two full-bridge structures, the current going through each full-bridge can not change instantaneously. Therefore either CBT or TSI should be included in the topology for proper current balancing.

\section{A. Discharge state}

Two extra modes can be defined in discharge state:

1) Mode 3 (Fig. 13): $S_{M 1}$ is ON and $S_{M 2}$ is OFF. When both modeling switches $S_{M 1}$ and $S_{M 2}$ are OFF, but $i_{2}>i_{1}$, this mode also can be created as diode $D_{M 1}$ is ON. 
2) Mode 4 (Fig. 14): $S_{M 1}$ is OFF and $S_{M 2}$ is ON. When both modeling switches $S_{M 1}$ and $S_{M 2}$ are OFF, but $i_{1}>i_{2}$, this mode also can be created as diode $D_{M 2}$ is ON.

Extra modes 3 and 4 are generally similar to mode 2; however currents $i_{1}$ and $i_{2}$ are not equal in these modes. As an example, assuming a delay for turning $S_{M 1} \mathrm{ON}$, we will investigate the operation of the converter in both CBT and TSI configurations.

1) CBT: When both switches $S_{M 1}$ and $S_{M 2}$ are OFF, converter is in mode 2 . When $S_{M 1}$ turns $\mathrm{ON}$ and $S_{M 2}$ is OFF (due to signaling mismatch), converter has mode 3 (Fig. 13-a). In this mode CBT sees a non-zero voltage; therefore magnetizing current of CBT is increasing. This current creates a current difference between two primary inverters. With turning $S_{M 2}$ ON, converter goes to mode 1, while there is a constant current difference between two primary bridges. When both switches turn OFF again (it is assumed no delay for turning OFF), converter can not enter to mode 2 because inverter currents are not same. Since $i_{1}$ is greater than $i_{2}$, simplified diode $D_{M 2}$ is forced to be ON and thus converter will be in mode 4 . During mode 4 , CBT sees negative non-zero voltage and magnetizing current of CBT is decreasing. Mode 4 continues until both inverter currents are the same. The required time interval for this is equal to the switching delay time interval between the two switches, $S_{M 1}$ and $S_{M 2}$. After mode 4, converter goes to mode 2. Fig. 15-a shows the waveforms of CBT topology in this condition.

2) TSI: When both switches $S_{M 1}$ and $S_{M 2}$ are OFF, converter is in mode 2. When $S_{M 1}$ turns ON and $S_{M 2}$ are OFF (due to signaling mismatch), converter is in mode 3 (Fig. 13-b). In this mode inductors see different voltages; $L_{1}$ sees positive voltage and $L_{2}$ sees negative voltage. This creates a current difference between the two inductors. With $S_{M 2}$ turning ON, converter goes to mode 1, while there is a constant current difference between the two primary bridges. When both turn OFF again, converter can not enter to mode 2 because inverter currents are not same. Since $i_{1}$ is greater than $i_{2}$, simplified diode $D_{M 2}$ is forced to be $\mathrm{ON}$ and thus converter will be in mode 4. During mode $4, L_{1}$ sees negative voltage and $L_{2}$ sees positive voltage. Therefore the current difference between the inductors is decreasing. Mode 4 continues until both bridge currents are the same. The required time interval for this is equal to the switching delay time interval between the two switches, $S_{M 1}$ and $S_{M 2}$. After mode 4, converter goes to mode 2. Fig. 15-b shows the waveforms of TSI topology in this condition. For both configurations, it can be proven that:

$V_{o}=\frac{2 n}{D^{\prime}+d_{o n}} V_{i}$
$I_{i}=\frac{2 n}{D^{\prime}+d_{o n}} I_{o}$

For both configurations, it can be seen from Fig. 15 that average of currents $i_{1}$ and $i_{2}$ are not equaled when there is a switching delay. Defining current difference $I_{d}$ as:

$I_{d}=0.5\left(I_{1}-I_{2}\right)$

Therefore for CBT and TSI configurations it can be written that:

$$
\begin{aligned}
I_{d-C B T} & =\frac{D d_{o n} V_{i}}{2 f_{S W} L_{m}\left(D^{\prime}+d_{o n}\right)} \\
I_{d-T S I} & =\frac{D d_{o n} V_{i}}{2 f_{S W} L\left(D^{\prime}+d_{o n}\right)}
\end{aligned}
$$

Therefore for $L=L_{m}$, both configurations have similar current difference. However assuming $\mathrm{d}_{o n}$ is small, current difference $\left(I_{d}\right)$ is small in both configurations.

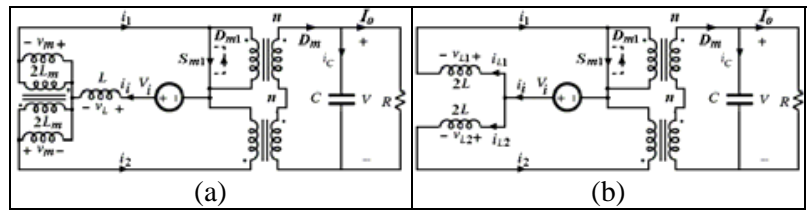

Fig. 13. Model of proposed conveteters in mode 3 of of discharging state: a) CBT b) TSI.

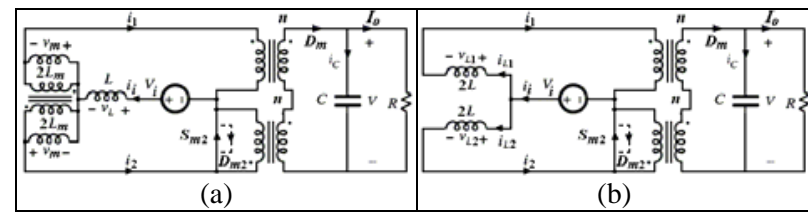

Fig. 14. Model of proposed conveteters in mode 4 of of discharging state: a) CBT b) TSI.

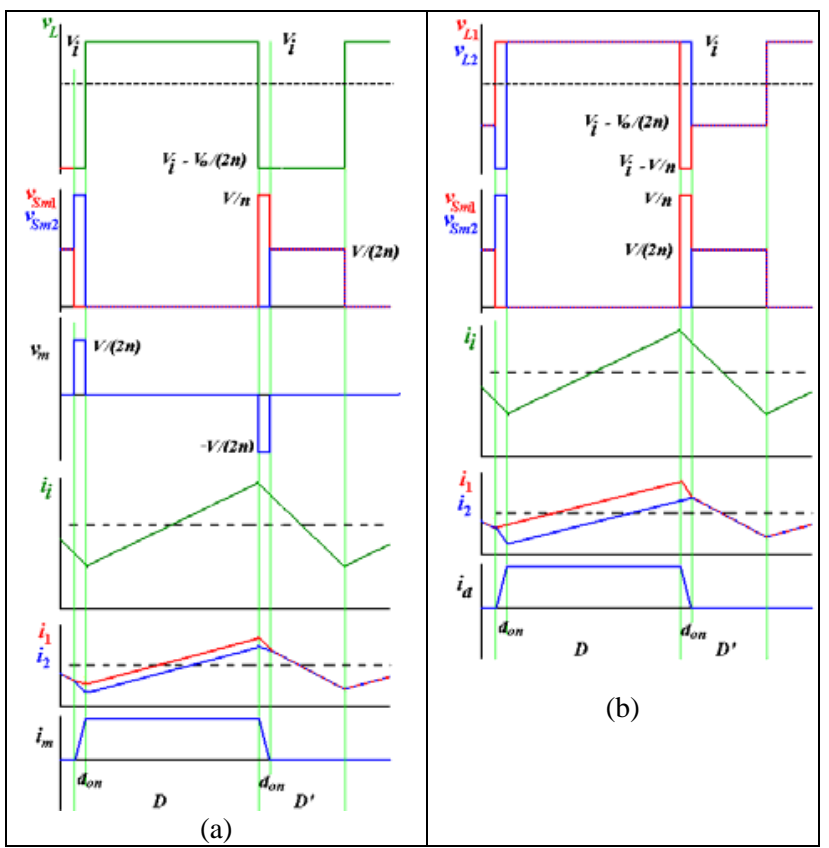

Fig. 15. Waveforms of proposed converters in discharging state with switching delay. 


\section{B. Charge state}

Similar to discharge state, two extra modes can be defined for charge state:

1) Mode 3 (Fig. 16): $D_{M 1}$ (or $S_{M 1}$ ) is $\mathrm{ON}$ and $D_{M 2}$ is OFF.

2) Mode 4 (Fig. 17): $D_{M 1}$ is OFF and $D_{M 2}\left(\right.$ or $S_{M 2}$ ) is ON.

Similar to discharge state, extra modes 3 and 4 are generally similar to mode 2 ; however currents $i_{1}$ and $i_{2}$ are not equal in these modes. In charge state, if switching delays are smaller than the deadtime, extra modes does not occur. However, extra modes can occur due to the difference between inductor values.

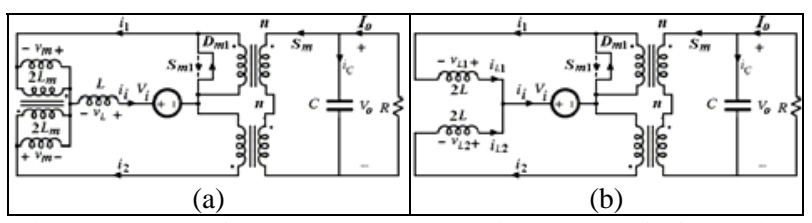

Fig. 16. Model of proposed conveteters in mode 3 of of charging state: a) CBT b) TSI.

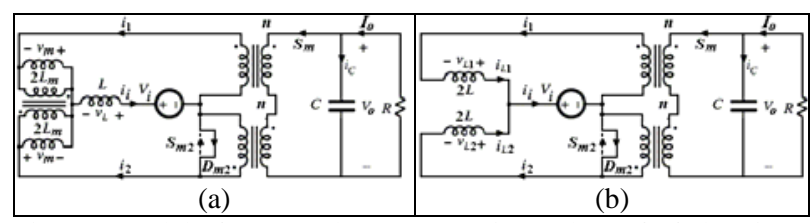

Fig. 17. Model of proposed conveteters in mode 4 of of charging state: a) CBT b) TSI.

\section{Control System}

A hybrid system such as in Fig. 1 usually includes a central control system (CCS) and several local control subsystems (Fig. 17-18). Regarding system condition, CCS determines references signals for the control subsystems.

In this paper, it is assumed that the reference current of SC is determined by CCS. Fig. 19 shows the control subsystem for the proposed converter for an SC application. Control system is based on average current mode control. A PI controller has been used for ensuring the steady state current error to be zero. Output of PI is a duty cycle value that it is applied to the PWM block.

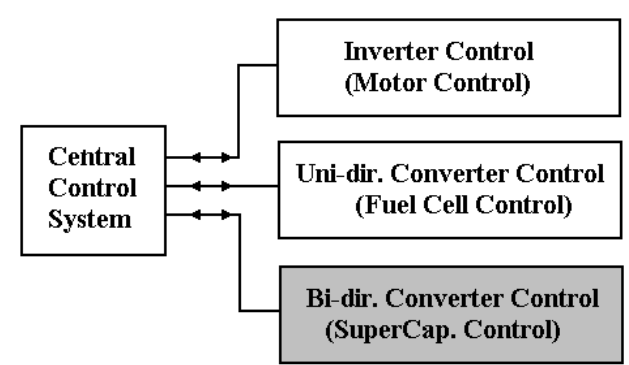

Fig. 17. Control system of FC-SC-Battery hybrid system (Fig. 1).

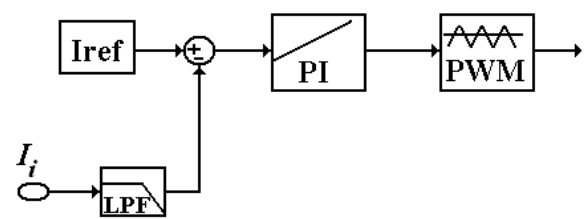

Fig. 18. Control subsystem of proposed bidirectional converter (supercapacitor).

\section{Simulation and Experiments}

To verify the proposed converter, the control system shown in Fig. 18 was used for simulation. Table 1 shows simulation parameters. A step signal has been used as the reference current; it changes from $-100 \mathrm{~A}$ to $100 \mathrm{~A}$ at $\mathrm{t}=2 \mathrm{~ms}$. Before $\mathrm{t}=2 \mathrm{~ms}$ the converter will be in the charge state and after that converter should go to the discharge state. Simulation results have been shown in Fig. 19. It can be seen that the SC current $\left(I_{i}\right)$ is able to track the reference current signal in both charge and discharge states.

An experimental prototype of the modified bidirectional DC-DC converter was also built using digital signal possessor (DSP) control (Fig. 20). Experimental current $I_{i}$ has been shown in Fig. 21. It could be observed that that the closed loop controller implemented in the DSP is able make the SC current follow the reference current in a stable manner. Implementation of the two transformers with primary parallel and secondary series connection is realized with planar E-type cores.

Table I. - Simulation Parameters

\begin{tabular}{|l|l|}
\hline Parameters & Values \\
\hline Capacitance of SC & $100 \mathrm{~F}$ \\
\hline Internal resistance of SC & 0.005 \\
\hline Initial voltage of SC & $25 \mathrm{~V}$ \\
\hline Battery voltage $\left(\mathrm{V}_{\mathrm{o}}\right.$ ) & $80 \mathrm{~V}$ \\
\hline Proportional gain $(\mathrm{Kp})$ of PI & 0.001 \\
\hline Integral gain (Ki) of PI & 10 \\
\hline Transformer turns ratio $(\mathrm{n})$ & 3 \\
\hline Inductors & $10 \mathrm{uH}$ \\
\hline Switching Frequency & $50 \mathrm{kHZ}$ \\
\hline
\end{tabular}



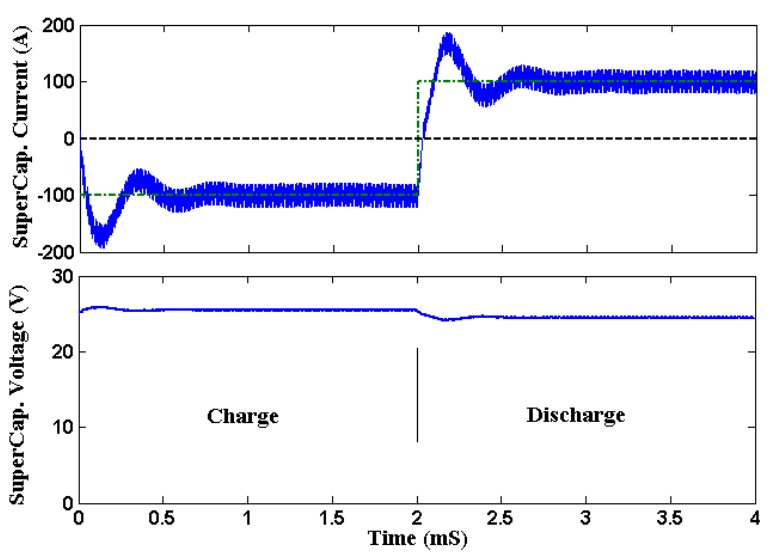

Fig. 19. Simulation results: Current and voltage of supercapacitor.

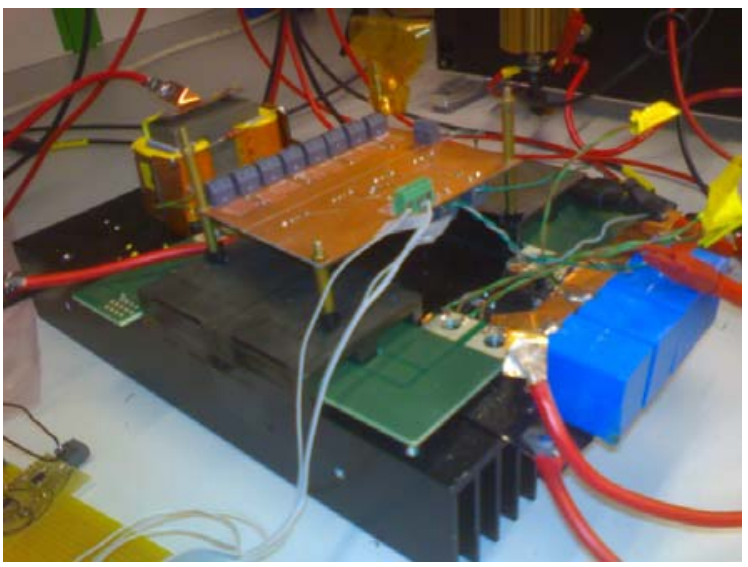

Fig. 20. Experimental prototype of the proposed converter.

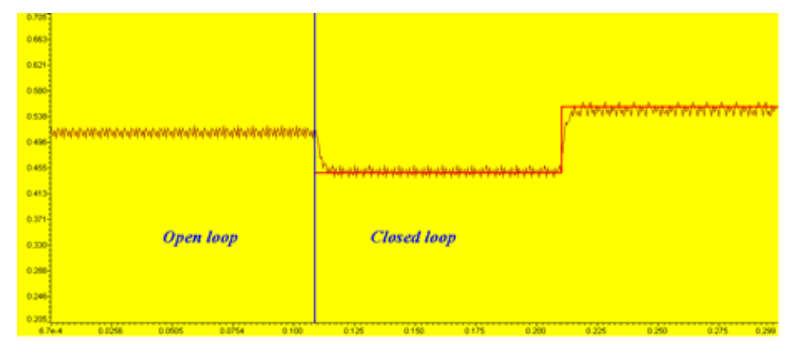

Fig. 21. Experimental results:Reference and (filtered) actual current (sampled by the DSP).

\section{Conclusion}

In this paper an isolated bidirectional DC/DC converter has been proposed for supercapacitor applications. The proposed converter uses a parallel structure on the primary side (low-voltage high-current side) and a series structure in secondary side (high-voltage low-current side). This structure has already been used for unidirectional power flow in the literature. It has been developed for bidirectional power flow in this paper. Also a new method was proposed for current sharing on the primary side. In the proposed method, separate inductors can be used instead of the conventional method which is based on a current balancing transformer. Although both methods have almost the same performance, manufacturing the separate inductors is easier. However, inductance value tolerances can be a problem in fair current distribution between the parallel primary stages. Performance and validity of the proposed converter has been verified by simulation and experimental results.

\section{References}

[1] Ke Jin, X. Ruan, M. Yang, and Min Xu, “A Hybrid Fuel Cell Power System,” IEEE Transactions on Industrial Electronics, vol. 56, no. 4, pp. 1212-1222, 2009.

[2] A. Sripakagorn, and N. Limwuthigraijirat, "Experimental assessment of fuel cell/supercapacitor hybrid system for scooters," International journal of hydrogen energy, vol. 34, pp. 6036-6044, 2009.

[3]P. Thounthong, S. Raël, and B. Davat, "Energy management of fuel cell/battery/supercapacitor hybrid power source for vehicle applications," Journal of Power Sources, vol. 193, pp. 376-385.

[4] H. Tao, A. Kotsopoulos, J. L. Duarte, and M. A. M. Hendrix, "A Soft-Switched Three-Port Bidirectional Converter for Fuel Cell and Supercapacitor Applications, Power Electronics Specialists Conference (PESC), 2005.

[5] F. Krismer, J. Biela, and J. W. Kolar, "A Comparative Evaluation of Isolated Bi-directional DC/DC Converters with Wide Input and Output Voltage Range," Fourtieth IAS Annual Meeting, 2005.

[6] Haimin Tao, Jorge L. Duarte, and Marcel A.M. Hendrix, "Multiport Converters for Hybrid Power Sources," Power Electronics Specialists Conference (PESC), 2008.

[7] Xin Kong, and A. M. Khambadkone, "Analysis and Implementation of a High Efficiency, Interleaved Current-Fed Full Bridge Converter for Fuel Cell System,” IEEE Transactions on Power Electronics, vol. 22, no. 2, pp. 543-550, 2007.

[8] M. Nymand, and M. A. E. Andersen, "A New Very-HighEfficiency R4 Converter for High-Power Fuel Cell Applications," Power Electronics and Drive Systems (PEDS), 2009. 